\title{
Application of Fine Compost and Husk Charcoal as a Source of Silica in Chrysanthemum Cultivation
}

\author{
Made Suarta $^{1}$, I Gusti Made Arjana ${ }^{2}$ \\ \{madesuarta11985@gmail1',igmarjana@gmail.com² \\ Fakultas Pertanian, Universitas Warmadewa, Denpasar, Bali, Indonesia
}

\begin{abstract}
The purpose of this study was to determine the dose of fine compost and husk charcoal, as a source of silica and its interactions in the cultivation of chrysanthemum. The research method used was the factorial randomized block design carried out in the field of a green house. Two factors were used in this study which are made up of fine compost consisting in 3 levels $-0.5,1.0$ and 1.5 tons ha ${ }^{-1}$, and husk charcoal, also in 3 levels - 100, 200 and $300 \mathrm{~kg} \mathrm{ha}^{-1}$. The results showed that the fine compost treatment had a very significant effect, at $\mathrm{P}<0.01$, on all the observed variables. In addition, the highest fresh weight of this economical flowers was $88.83 \mathrm{~g}$, produced by the treatment with 1.5 tons $\mathrm{ha}^{-1}$ dose of fine compost. Also, this resulted to an increase in yield by $23.04 \%$ compared to the fine compost with the lowest treatment dosage. Similarly, the treatment with husk charcoal had a significant effect, at $\mathrm{P}<0.05$, on the maximum plant height, flower stem length, and flower diameter. It also had a very significant effect, at $\mathrm{P}<0.01$, on the stem diameter, flower stem weight, and fresh weight of the economical flowers. The treatment of husk charcoal with a dose of $300 \mathrm{~kg} \mathrm{ha}^{-1}$ produced the highest fresh weight of $80.78 \mathrm{~g}$. This resulted in an increase in yield by $53.73 \%$ compared to the treatment with the lowest dosage. However, the interaction between the two treatments had no significant effect on all observed variables.
\end{abstract}

Keywords: fine compost; husk charcoal; chrysanthemum

\section{Pendahuluan}

Perkembangan pariwisata yang semakin pesat juga memberikan dampak kepada beragamnnya produk-produk hortikultura yang dibutuhkan untuk memenuhi tuntutan pasar yang berkualitas dan kontinyuitas produk terjamin, terkait Bali merupakan daerah pariwisata sehingga potensi pasar krisan sangat menjanjikan baik untuk konsumen individu seperti: florist, acara perkawinan dan hari-hari besar. Serta konsumen institusi (hotel, bank dan kantor pemerintah dan swasta) sehingga dengan demikian pengembangan tanaman hias diarahkan mengacu pada kebutuhan pasar, serta keuntungan komperatif dan bernilai ekonomis. Tanaman Krisan merupakan komoditas yang penting di dunia pada perdagangan internasional dan memiliki nilai ekonomis yang cukup tinggi sehingga potensial untuk dikembangkan secara komersial. Prospek budidaya krisan sebagai bunga potong sangat cerah, karena pasar potensial yang dapat berdaya serap tinggi masih sangat terbuka lebar terkait dengan kebutuhan pasar 
yang sangat luas selain pasar eksport juga pasar lokal. Saat ini krisan termasuk bunga paling populer di Indonesia sebagai bunga potong, karena memiliki keunggulan kaya akan warna, beragam varietas, bentuk dan tahan lama [1]. Bunga krisan memiliki nilai ekonomi yang cukup tinggi dan potensial dikembangkan sebagai komponen dasar dalam agribisnis baik sebagai bunga potong, tanaman hias dalam pot, maupun tanaman obat [2].

Usaha budidaya krisan telah berkembang di berbagai sentra produksi di Indonesia sebagai sumber pendapatan petani yang menguntungkan. Seiring dengan meningkatnya permintaan pasar, usaha budidaya krisan yang awalnya terkonsentrasi di Pulau Jawa, kini telah menyebar luas ke Bali. Selain itu pengembangannya sesui dengan potensi sumberdaya, kondisi agroklimat, agroekosistem suatu wilayah, sarana dan prasarana pendukung serta prospek pasar.Belum semua daerah yang potensial telah ditanami tanaman hias, karena berbagai pertimbangan misalnya letaknya yang jauh dari pusat pemasaran, tidak terdapat prasarana yang memadai, keterbatasan pengetahuan budidaya, pemanenan, maupun penanganan pasca panen serta agroklimat yang tidak sesuai dengan budidaya tanaman krisan [3].

Permasalahan yang dihadapi petani krisan di sentra baru di luar pulau Jawa khususnya Bali adalah pengetahuan tentang budidaya tanaman krisan, salah satunya menyangkut teknik budidaya dalam hal pemeliharaan yaitu pemupukan dengan pupuk organik pada sentra pengembangan baru, karena setiap lahan yang akan diusahakan memiliki kondisis yang berbeda, yang akan berdampak pada pertumbuhan dan perkembangan tanaman yang tidak sesuai dengan mutu standar yang diinginkan. Penetapan dosis untuk fine compost dan arang sekam yang kurang sesuai dengan kondisi budidaya, merupakan penyebab rendahnya produksi dan kualitas bunga krisan yang berpengaruh terhadap harga jual krisan sebagai bunga potong. Berdasarkan hal tersebut di atas, maka perlu dilakukan penelitian aplikasi fine compost dan arang sekam sebagai sumber silika pada pada tanaman hias krisan.

Perkembangan pariwisata yang semakin pesat juga memberikan dampak kepada beragamnnya produk-produk hortikultura yang dibutuhkan untuk memenuhi tuntutan pasar yang berkualitas dan kontinyuitas produk terjamin, terkait Bali merupakan daerah pariwisata sehingga potensi pasar krisan sangat menjanjikan baik untuk konsumen individu seperti: florist, acara perkawinan dan hari-hari besar. Serta konsumen institusi (hotel, bank dan kantor pemerintah dan swasta) sehingga dengan demikian pengembangan tanaman hias diarahkan mengacu pada kebutuhan pasar, serta keuntungan komperatif dan bernilai ekonomis. Tanaman Krisan merupakan komoditas yang penting di dunia pada perdagangan internasional dan memiliki nilai ekonomis yang cukup tinggi sehingga potensial untuk dikembangkan secara komersial. Prospek budidaya krisan sebagai bunga potong sangat cerah, karena pasar potensial yang dapat berdaya serap tinggi masih sangat terbuka lebar terkait dengan kebutuhan pasar yang sangat luas selain pasar eksport juga pasar lokal. Saat ini krisan termasuk bunga paling populer di Indonesia sebagai bunga potong, karena memiliki keunggulan kaya akan warna, beragam varietas, bentuk dan tahan lama [1]. Bunga krisan memiliki nilai ekonomi yang cukup tinggi dan potensial dikembangkan sebagai komponen dasar dalam agribisnis baik sebagai bunga potong, tanaman hias dalam pot, maupun tanaman obat [2]. 
Usaha budidaya krisan telah berkembang di berbagai sentra produksi di Indonesia sebagai sumber pendapatan petani yang menguntungkan. Seiring dengan meningkatnya permintaan pasar, usaha budidaya krisan yang awalnya terkonsentrasi di Pulau Jawa, kini telah menyebar luas ke Bali. Selain itu pengembangannya sesui dengan potensi sumberdaya, kondisi agroklimat, agroekosistem suatu wilayah, sarana dan prasarana pendukung serta prospek pasar. Belum semua daerah yang potensial telah ditanami tanaman hias, karena berbagai pertimbangan misalnya letaknya yang jauh dari pusat pemasaran, tidak terdapat prasarana yang memadai, keterbatasan pengetahuan budidaya, pemanenan, maupun penanganan pasca panen serta agroklimat yang tidak sesuai dengan budidaya tanaman krisan [3].

Permasalahan yang dihadapi petani krisan di sentra baru di luar pulau Jawa khususnya Bali adalah pengetahuan tentang budidaya tanaman krisan, salah satunya menyangkut teknik budidaya dalam hal pemeliharaan yaitu pemupukan dengan pupuk organik pada sentra pengembangan baru, karena setiap lahan yang akan diusahakan memiliki kondisis yang berbeda, yang akan berdampak pada pertumbuhan dan perkembangan tanaman yang tidak sesuai dengan mutu standar yang diinginkan. Penetapan dosis untuk fine compost dan arang sekam yang kurang sesuai dengan kondisi budidaya, merupakan penyebab rendahnya produksi dan kualitas bunga krisan yang berpengaruh terhadap harga jual krisan sebagai bunga potong. Berdasarkan hal tersebut di atas, maka perlu dilakukan penelitian aplikasi fine compost dan arang sekam sebagai sumber silika pada pada tanaman hias krisan.

\section{Metodologi}

Metode penelitian menggunakan rancangan acak kelompok pola faktorial yang dilakukan dilapangan dalam rumah plastic. Pada penelitian ini menggunakan dua faktor yaitu : factor pertama fine compost (F) terdiri dari 3 taraf masing-masing terdiri dari : 0,5 ton ha-1, 1.0 ton ha-1 , dan 1,5 ton ha-1. Faktor kedua arang sekam terdiri dari 3 taraf yaitu : $100 \mathrm{~kg}$ ha-1, $200 \mathrm{~kg}$ ha-1 , dan $300 \mathrm{~kg}$ ha-1. Perlakuan kombinasi berjumlah 9 diulang sebanyak 3 kali, sehingga diperlukan 27 petak percobaan. Apabila analisis ragam menujukkan pengaruh nyata sampai sangat nyata terhadap faktor tunggal dilanjutkan dengan uji jarak nyata terkecil (BNT) dan uji Duncan' apabila interaksi berpangaruh nyata sampai sangat nyata [4].

Pelaksanaan percobaan meliputi : persiapan media, membersihkan, mengolah dan meratakan lahan untuk budidaya krisan potong serta menyediakan tempat sistem perakaran tanaman yang sesuai untuk produksi bunga potong, mengatur aerasi tanah untuk menjaga pertukaran udara di dalam tanah dan sesuai dengan standar prosedur pengolahan lahan. Sebelum tanah diolah lahan dibersihkan dari sisa tanaman, lahan dicangkul sedalam $30 \mathrm{~cm}$, kemudian dilakukan perataan tanah. Pembuatan bedengan, setelah tanah diolah kemudian dibuatkan bedengan dengan ukuran $1 \mathrm{~m}$ x $1 \mathrm{~m}$, jarak antar bedengan $30 \mathrm{~cm}$, sedangkan jarak antar ulangan $50 \mathrm{~cm}$. Selanjutnya dilakukan pemupukan sesuai perlakuan dan pupuk dasar. 
Pemupukan, dilakukan pemupukan sesuai dengan perlakuan yang dicoba, dan pemberian pupuk anorganik sebagai pupuk dasar dengan dosis pemupukan dilakukan setelah tanaman berumur sekitar 2 minggu dengan $1,5 \mathrm{~g} / \mathrm{m}^{2}$ urea daplikasikan melalui siraman atau irigasi tetes. Selanjutnya dengan dosis yang sama dilakukan pada umur 4 dan 6 minggu. Pemupukan lanjutan terakhir dilakukan pada saat tanaman berumur 8 minggu dengan menggunakan 1,5 $\mathrm{g} / \mathrm{m}^{2}$ urea dan $6 \mathrm{~g} / \mathrm{m}^{2} \mathrm{SP} 36$.

Penanaman, dilakukan pada sore hari dengan jarak tanam $12,5 \mathrm{~cm} \times 12,5 \mathrm{~cm}$. Pemeliharaan tanaman, penyiraman dilakukan dengan irigasi tetes disesuai dengan keadaan kondisi dilapangan, penyulaman dilakukan setelah tanaman berumur seminggu setelah tanam, penyiangan disesuaikan dengan pertumbuhan tanaman pengganggu yang tumbuh dilapangan, pengendalian hama dan penyakit disesuaikan dengan jenis organisme penggangu tanaman dengan konsentrasi pestisida yang sesuai dengan fungsinya untuk mengendalikan organisme pengganggu tanaman tersebut. Pengamatan pertumbuhan dan perkembangan tanaman sampai panen. Variabel yang dimati meliputi : tinggi tanaman maksimum $(\mathrm{cm})$ diamati pada umur dua minggu setelah penanaman, pengukuran dilanjutkan setiap minggu sampai ketinggian maksimum tercapai. Panjang tangkai bunga $(\mathrm{cm})$ pengukuran dilakunan sebelum panen, dengan mengukur panjang tangkai bunga dari permukaan tanah sampai ujung bunga tertinggi. Diameter batang $(\mathrm{cm})$ diukur dengan jangka sorong menjelang panen, dengan cara mengukur batang tanaman antara tinggi maksimum. Diameter bunga $(\mathrm{cm})$ diukur dengan menggunakan jangka sorong dari bunga yang telah mekar penuh. Berat tangkai bunga (g) diukur dengan menimbang tangkai bunga setelah dipotong dengan timbangan elektrik. Berat segar bunga ekonomis (g) diukur dengan menimbang bunga segar yang bernilai ekonomis sepanjang $80 \mathrm{~cm}$ setelah panen dengan timbangan elektrik.

\section{Hasil Dan Pembahasan}

Signifikansi hasil pengaruh perlakuan fine compost dan arang sekam serta interaksinya pada semua variabel yang diamati pada tanaman krisan tersaji pada Tabel 1. Hasil pengaruh rata-rata antara perlakuan fine compost dan arang sekam pada tinggi tanaman maksimum $(\mathrm{cm})$, panjang tangkai bunga $(\mathrm{cm})$, diameter batang $(\mathrm{cm})$, diameter bunga $(\mathrm{cm})$, berat tangkai bunga $(\mathrm{g})$, dan berat segar bunga ekonomis (g) tersaji pada Tabel 2 .

Tabel 1. Signifikansi hasil analisis varians pengaruh perlakuan fine compost dan arang sekam serta interaksinya pada semua variabel yang diamati pada tanaman krisan

\begin{tabular}{lcccc}
\hline No & Variabel & \multicolumn{2}{c}{ Perlakuan } \\
\cline { 3 - 5 } & & Fine compost & Arang sekam & Fine compost x Arang sekam \\
\hline 1 & Tinggi tanaman maksimum $(\mathrm{cm})$ & $* *$ & $*$ & th \\
2 & Panjang tangkai bunga $(\mathrm{cm})$ & $* *$ & $*$ & tn
\end{tabular}




$\begin{array}{lllll}3 & \text { Diameter batang }(\mathrm{cm}) & * * & * * & \text { tn } \\ 4 & \text { Diameter bunga }(\mathrm{cm}) & * * & * & \text { tn } \\ 5 & \text { Berat tangkai bunga }(\mathrm{g}) & * * & * * & \text { tn } \\ 6 & \text { Berat segar bunga ekonomis }(\mathrm{g}) & * * & * * & \text { tn }\end{array}$

Keterangan: $*$ = berpengaruh nyata, ${ }^{* *}=$ berpengaruh sangat nyata, $\mathrm{tn}=$ tidak nyata.

Hasil analisis varians menunjukkan bahwa, perlakuan fine compost berpengaruh sangat nyata $(\mathrm{P}<0.01)$ pada semua variabel yang diamati. Sedangkan perlakuan arang sekam nampak memberikan pengaruh nyata pada tinggi tanaman maksimum, panjang tangkai bunga, dan diameter bunga, serta berpengaruh sangat nyata pada variabel diameter batang, berat tangkai bunga, dan berat segar bunga ekonomis. Hal ini menunjukkan bahwa setiap perlakuan yang dicoba memberikan respon yang berbeda terhadap variabel pertumbuhan vegetatif dan generatif pada tanaman krisan Tabel 2.

Sedangkan interaksi antara perlakuan fine compost dan arang sekam tidak memberikan pengaruh yang nyata pada semua variabel yang diamati pada pertumbuhan dan perkembangan tanaman krisan, hal ini disebabkan fine compost dan arang sekam pada setiap dosis memberikan pengaruh yang sama. Hal in juga berarti jika tidak ada interaksi maka berarti tidak ada pengaruh bersama antara fine compost dan arang sekam, dan hanya ada pengaruh sendiri dari masing-masing kedua faktor.

Tabel 2. Rata-rata pengaruh perlakuan fine compost dan arang sekam pada semua variabel yang diamati

\begin{tabular}{|c|c|c|c|c|c|c|}
\hline Perlakuan & $\begin{array}{l}\text { Tinggi } \\
\text { tanaman } \\
\text { maksimum } \\
(\mathrm{cm})\end{array}$ & $\begin{array}{c}\text { Panjang } \\
\text { tangkai } \\
\text { bunga }(\mathrm{cm})\end{array}$ & $\begin{array}{c}\text { Diameter } \\
\text { batang } \\
(\mathrm{cm})\end{array}$ & $\begin{array}{c}\text { Diameter } \\
\text { bunga }(\mathrm{cm})\end{array}$ & $\begin{array}{c}\text { Berat } \\
\text { tangkai } \\
\text { bunga }(g)\end{array}$ & $\begin{array}{l}\text { Berat segar } \\
\text { bunga } \\
\text { ekonomis }(\mathrm{g})\end{array}$ \\
\hline \multicolumn{7}{|c|}{ Fine Compost } \\
\hline $\begin{array}{l}0,5 \text { ton } \\
\mathrm{ha}^{-1}\end{array}$ & $113.75 \mathrm{c}$ & $131.59 \mathrm{c}$ & $2.15 \mathrm{c}$ & $8.94 \mathrm{c}$ & $135.77 \mathrm{c}$ & $68.36 \mathrm{c}$ \\
\hline $\begin{array}{l}1.0 \text { ton } \\
\mathrm{ha}^{-1}\end{array}$ & $122.14 \mathrm{~b}$ & $142.41 \mathrm{~b}$ & $2.43 \mathrm{~b}$ & $10.91 \mathrm{~b}$ & $172.02 \mathrm{~b}$ & $79.86 \mathrm{~b}$ \\
\hline $\begin{array}{l}1,5 \text { ton } \\
\mathrm{ha}^{-1}\end{array}$ & $130.74 \mathrm{a}$ & $147.35 \mathrm{a}$ & $2.93 \mathrm{a}$ & $11.76 \mathrm{a}$ & $191.50 \mathrm{a}$ & $88.83 \mathrm{a}$ \\
\hline BNT 5\% & 3.34 & 3.56 & 0.12 & 0.75 & 10.27 & 2.51 \\
\hline
\end{tabular}

Arang sekam 


\begin{tabular}{lrrrrrr}
$100 \mathrm{~kg} \mathrm{ha}^{-1}$ & $119.65 \mathrm{~b}$ & $137.97 \mathrm{~b}$ & $2.38 \mathrm{~b}$ & $9.86 \mathrm{c}$ & $157.53 \mathrm{~b}$ & $76.44 \mathrm{~b}$ \\
$200 \mathrm{~kg} \mathrm{ha}^{-1}$ & $122.63 \mathrm{ab}$ & $140.86 \mathrm{ab}$ & $2.48 \mathrm{~b}$ & $10.73 \mathrm{~b}$ & $164.44 \mathrm{~b}$ & $79.81 \mathrm{a}$ \\
$300 \mathrm{~kg} \mathrm{ha}^{-1}$ & $124.34 \mathrm{a}$ & $142.52 \mathrm{a}$ & $2.65 \mathrm{a}$ & $11.02 \mathrm{a}$ & $177.31 \mathrm{a}$ & $80.78 \mathrm{a}$ \\
\hline BNT $5 \%$ & 3.34 & 3.56 & 0.12 & 0.75 & 10.27 & 2.51 \\
\hline
\end{tabular}

Perlakuan fine compost menghasilkan pertumbuhan dan perkembangan tinggi tanaman maksimum, panjang tangkai bunga, diameter batang, diameter bunga, berat tangkai bunga, dan berat segar bunga ekonomis tertinggi. Sedangkan rata-rata hasil tertinggi pada perlakuan fine compost disetiap variabel terdapat pada dosis 1,5 ton ha-1 masing-masing sebesar : $130.74 \mathrm{~cm}$, $73.59 \mathrm{~g}, 147.35 \mathrm{~cm}, 2.9 \mathrm{~cm}, 11.76 \mathrm{~cm}, 191.50 \mathrm{~g}$, dan $88.83 \mathrm{~g}$. Perlakuan fine compost terendah terdapat pada dosis 0,5 ton ha- 1 dan berbeda nyata pada setiap taraf dosis yang dicoba. Berat segar bunga ekonomis tertinggi sebesar $88.83 \mathrm{~g}$ dihasilkan oleh perlakuan dosis fine compost 1,5 ton ha-1, dan terendah dihasilkan pada perlakuan fine compost dosis 0,5 ton ha-1 sebesar 68.36 g. Terjadi peningkatan hasil sebesar $23.04 \%$ jika dibandingkan dengan perlakuan fine compost terendah. Berat segar bunga ekonomis pada perlakuan dosis fine compost 1,5 ton ha- 1 berpengaruh nyata dengan taraf dosis yang lainnya pada setiap variabel yang diamati (Tabel 2).

Tingginya hasil pertumbuhan dan perkembangan tanaman akibat perlakuan fine compost dosis 1,5 ton ha-1 disebabkan kandungan unsur dari fine compost terdiri dari unsur makro dan mikro seperti : $1.81 \% \mathrm{~N}, 2.763 \% \mathrm{P} 2 \mathrm{O} 5,1.96 \% \mathrm{~K} 2 \mathrm{O}, 2.96 \% \mathrm{CaO}, 3.18 \% \mathrm{MgO}$, dan unsur hara mikro : Cu, B, Mo, Zn (Instalasi Penelitian dan Pengkajian Teknologi Pertanian, 2000). Nitrogen berperan dalam membantu pertumbuhan vegetatif tanaman, menyusun zat hijau daun, protein dan lemak. Fosfor berperan penting dalm kegiatan penyusunan inti sel lemak dan protein tanaman, serta berfungsi untuk merangsang pembentukan bunga, buah dan biji. Kalium berfungsi sebagai penyusun protein dan karbohidrat pada tanaman, dalam pertumbuhan tanaman kalium berperan dalam memperkuat kayu tanaman, meningkatkan kualitas buah, serta meningkatkan ketahanan terhadap hama, penyakit, dan kekeringan. Kalsium berperan sebagai pembentuk dinding sel tanaman, mengeraskan bagian kayu tanaman, merangsang pertumbuhan akar, mempertebal dinding sel buah, dan merangsang pertumbuhan biji. Magnesium bermanfaat dalam penyusunan klorofil, mengaktifkan enzim yang berhubungan dengan metabolisme karbohidrat, dan menambah kadar minyak pada tanaman [5]. Boron membantu transportasi karbohidrat keseluruh bagian tanaman, Zn Dalam jumlah yang sangat sedikit dapat mendorong laju pertumbuhan tanaman, Mn berperanan penting dalam proses asimilasi, $\mathrm{Cu}$ berperan penting dalam pembentukan zat hijau daun (klorofil). Karena dalam pertumbuhan dan perkembangan tanaman krisan sangat memerlukan unsur-unsur tersebut yang berdampak pada pengaruh terhadap variabel yang diamati, semakin tinggi dosis yang diberikan maka kandungan unsur akan semakin meningkat. 
Perlakuan arang sekam $300 \mathrm{~kg}$ ha-1 berpengaruh nyata pada setiap variabel yang diamati, kecuali berpengaruh tidak nyata dengan dosis arang sekam $200 \mathrm{~kg}$ ha-1 pada variabel tinggi tanaman maksimum, panjang tangkai bunga, dan berat segar bunga ekonomis. Sedangkan perlakuan dosis arang sekam $200 \mathrm{~kg}$ ha-1berpengaruh tidak nyata dengan perlakuan arang sekam $100 \mathrm{~kg}$ ha-1 pada variable tinggi tanaman maksimum, panjang tangkai bunga, diameter batang, dan berat tangkai bunga (Tabel 2)

Berat segar bunga ekonomis tertinggi sebesar $80.78 \mathrm{~g}$ dihasilkan oleh perlakuan dosis arang sekam 300 ton ha-1, dan terendah dihasilkan pada perlakuan arang sekam dosis 100 ton ha-1 sebesar 76.44 g. Terjadi peningkatan hasil sebesar 53.73\% \% jika dibandingkan dengan perlakuan dosis arang sekam terendah. Berat segar bunga ekonomis pada perlakuan dosis arang sekam 300 ton ha-1 berpengaruh tidak nyata dengan perlakuan arang sekam dosis 100 ton ha-1 (Tabel 2).Peningkatan pertumbuhan dan perkembangan tanaman pada setiap variabel yang diamati pada perlakuan dosis arang sekam 300 ton ha-1 disebabkan arang sekam sebagai media tanam memiliki kandungan karbon yang tinggi. Arang sekam banyak dimanfaatkan sebagai campuran media tanam. Arang sekam merupakan media tanam yang baik karena memiliki kandungan $\mathrm{SiO} 252 \%$ (Wuryan, 2008 in [6], dan unsur C 31\%. Kandungan unsur hara pada arang sekam antara lain kalium $0,31 \%$, N 0,32\%, P 0,15\%, Ca 0,96\%. Kandungan $\mathrm{SiO} 2$ yang tinggi pada arang sekam berperanan untuk memperkuat berdiri tegaknya tanaman, dengan pemberian arang sekam memberikan pengaruh pada tanaman krisan pada tinggi tanaman, panjang tangkai bunga dan diameter batang memberikan pengaruh yang nyata. Unsur hara yang lain terkandung dalam arang sekam memberikan pengaruh nyata pada variabel yang lainnya (Tabel 2).

\section{Kesimpulan}

Berdasarkan hasil penelitian di atas, maka dapat disimpulkan bahwa 1) Interaksi antara perlakuan fine compost dan arang sekam tidak memberikan pengaruh yang nyata pada semua variabel yang diamati. 2) Perlakuan fine compost memberikan pengaruh sangat nyata $(\mathrm{P}<$ 0.01) pada semua variabel yang diamati. Berat segar bunga ekonomis tertinggi sebesar $88.83 \mathrm{~g}$ dihasilkan oleh perlakuan dosis fine compost 1,5 ton $\mathrm{ha}^{-1}$, terjadi peningkatan hasil sebesar 23.04\% jika dibandingkan dengan perlakuan fine compost terendah. 3) Perlakuan arang sekam berpengaruh nyata $(\mathrm{P}<0.05)$ pada tinggi tanaman maksimum, panjang tangkai bunga, dan diameter bunga, serta berpengaruh sangat nyata $(\mathrm{P}<0.01)$ pada variabel diameter batang, berat tangkai bunga, dan berat segar bunga ekonomis. Perlakuan dosis arang sekam $300 \mathrm{~kg}$ ha${ }^{1}$ menghasilkan berat segar bunga ekonomis tertinggi sebesar $80.78 \mathrm{~g}$, terjadi peningkatan hasil sebesar $53.73 \%$ jika dibandingkan dengan perlakuan arang sekam terendah. Dengan demikian, disarankan untuk budidaya tanaman krisan dapat diaplikasikan fine kompos dengan dosis 1,5 ton ha $\mathrm{h}^{-1}$ atau arang sekam dengan dosis $300 \mathrm{~kg} \mathrm{ha}^{-1}$ 


\section{References}

[1] D. Sartika, Krisan Baru Produk Indonesia. Trubus No. 342. 1998.

[2] H. Rukmana, Krisan. Yogyakarta: Kanisius, 1997.

[3] Darti, Tanaman dan Budidaya Tanaman Hias. Jakarta: PD. Mahkota, 1992.

[4] K. A. Hanafiah, Rancangan Percobaan, Teori \& Aplikasi. Jakarta: PT. Raja Grafindo, 2001.

[5] H. O. Buckman and N. C. Brady, Ilmu Tanah. Jakarta: Bharata Karya Aksara, 1982.

[6] H. Gustia, "Pengaruh Penambahan Sekam Bakar Pada Media Tanam Terhadap Pertumbuhan dan Produksi Tanaman Sawi (Brassica juncea L.)," E-Journal WIDYA Kesehat. dan Lingkung., vol. 1, no. 1, pp. 12 $17,2013$. 